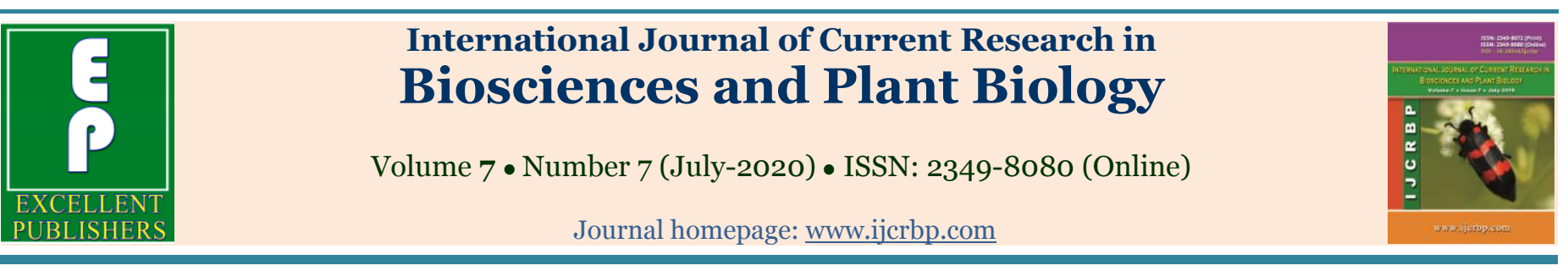

\title{
Infant powdered milk formula and milk powder as a potential risk for developing children in terms of Aflatoxin M1
}

\author{
Maria Ahmed El-Ansary* \\ Food Control Department, Faculty of Veterinary Medicine, Alexandria University, Egypt \\ *Corresponding author; e-mail: mariaelansary@yahoo.com
}

\begin{tabular}{|c|c|}
\hline Article Info & ABSTRACT \\
\hline $\begin{array}{l}\text { Date of Publication: } \\
\text { o6 July } 2020\end{array}$ & \multirow{3}{*}{$\begin{array}{l}\text { Milk powder is widely consumed across age groups, especially by Egyptian children. } \\
\text { The possible presence of Aflatoxin M1 (AFM1) in milk and milk products is a worldwide } \\
\text { concern since these products are largely consumed by children, including infants, who a } \\
\text { reconsidered more susceptible to the adverse effects of mycotoxins. Therefore, the } \\
\text { presence of AFM1 in infant milk formula and milk powder is a significant problem for } \\
\text { human health especially for children. The aim of this study was to investigate the } \\
\text { incidence and levels of AFM1 in infant powdered milk formula and powdered milk } \\
\text { samples in El-Behera, Egypt. The AFM1 levels of the samples were determined using } \\
\text { high performance liquid chromatography for separation and fluorescence detection. A } \\
\text { total of } 100 \text { samples (50 each of infant milk formulas and milk powder) were analyzed } \\
\text { for AFM1. The results revealed that } 6(12 \%) \text { of infant powdered milk samples and } \\
12(24 \%) \text { of examined powdered milk were contaminated. The mean levels of AFM1 in } \\
\text { the samples were } 17.3 \pm 1.29 \text { and } 15.9 \pm 2.26 \text { (ng/kg) for infant powdered milk and } \\
\text { powdered milk; respectively. Only } 4(8 \%) \text { of infant powdered milk samples and } 6(12 \%) \\
\text { of powdered milk samples exceeded the safety limits for AFM1established by the } \\
\text { European commission ( } 25 \mathrm{ng} / \mathrm{kg} \text { ) and (50 ng/ kg) in infant milk formulae and milk } \\
\text { powder; respectively. The estimated daily intake (EDI) of AFM1 was evaluated, and the } \\
\text { average intake was }(81,63.93,37.57 \text { and } 39) \text { ng/kg body weights for (one week of age, } \\
\text { one month, } 6 \text { months and } 12 \text { months of age for infants; respectively and EDI was } \\
14.24 n g / k g \text { body weights for adults. Values of EDI of AFM1 found in El-Behera, } \\
\text { Egyptpose a toxicological risk to the consumers in various age groups. The results of } \\
\text { this study showed the necessity of regular monitoring for the occurrence of AFM1 in } \\
\text { infant powdered milk and milk powder for adult's consumption. }\end{array}$} \\
\hline Keywords & \\
\hline $\begin{array}{l}\text { Aflatoxin M1 } \\
\text { Mycotoxins } \\
\text { Infant formula } \\
\text { Milk Powder }\end{array}$ & \\
\hline
\end{tabular}

\section{Introduction}

Aflatoxins (AFs) are fungal secondary metabolites that are primarily produced by Aspergillus flavus and Aspergillus parasiticus. Aflatoxins have been detected in a variety of agricultural commodities, but the most pronounced contamination is related to corn, peanuts, cottonseed, and tree nuts (IARC, 2002). The incidence and occurrence of AflatoxinM1 (AFM1) contamination in milk and dairy products depend on the country of origin and the presence of AFM1 in milk and dairy products is an important issue, especially for developing countries (Prandini et al., 2009).It is important to 
determine AFM1 levels in milk and dairy products in order to protect consumers in various age groups, from its potential hazards. The incidence of AFM1 in milk is a serious public health concern, especially for children who are more susceptible to the effects of AFM1 than adults (Ameur et al., 2020). In Egypt in 2018; the production of milk was 7.2 million tons; milk production per capita was $76 \mathrm{~kg}$; milk consumption was estimated at $97.8 \mathrm{~kg}$ per capita per year; in Egypt we should import milk powder to cover this gape. AFM1 is resistant to thermal inactivation, pasteurization, autoclaving and other varieties of food processing procedures (Boudra et al., 2007). A linear relationship has been established between the amount of AFM1 in milk and the amount of AflatoxinB1 (AFB1) in feed consumed by animals, emphasized at first on the reduction or removal of AFB1 from feedstuffs and then elimination of AFM1 from milk. It has been demonstrated that up to $6 \%$ of the ingested AFB1 is secreted into the milk as AFM1 (Van Egmond and Dragacci, 2001). It is possible for milk powder to contain AFM1, if made from contaminated raw milk. The International Agency for Research on Cancer (IARC, 2002) classified AFB1 as a class 1 human carcinogen and AFM1 as a secondary group of carcinogenic compounds (Creppy, 2002). The carcinogenic potency of AFM1 is less than aflatoxin B1. Toxicological evaluation of aflatoxin over food intake is essential to any risk evaluation and important for determining the relationship observed in humans and exposure to aflatoxin (Shundo et al., 2009). Codex Alimentarius and European Communities (EFSA 2004) prescribe a limit of $50 \mathrm{ng} / \mathrm{kg}$ AFM1 in milk and $25 \mathrm{ng} / \mathrm{kg}$ for infant milk products. Studies have shown that the presence of AFM1 in milk and milk products is a health issue because in many countries, every age group regularly consumed these products in their daily diet (Fallah et al., 2009). The aim of the present study was to evaluate the natural occurrence of AFM1 in infant milk formulae and milk powder from El-Behera; Egypt and to assess the health risks to the consumers and to estimate the daily AFM1 intake of children and adult consumers.

\section{Materials and methods}

A total of one hundred (50 infant formulas from 6 different imported brands and 50 milk powders for adult consumption) samples were collected randomly from different super markets located in El-Behera province, Egypt. The collected samples were transferred directly to the laboratory with a minimum time of delay under aseptic condition. AFM1 estimation in samples infant milk formulas and milk powder including, samples preparation, toxin extraction, toxin elution and measure with HPLC.

\section{Reagents}

An AFM1 standard was purchased from Sigma Chemical (St. Louis, MO).HPLC grade acetonitrile and water were purchased from Fisher Scientific (Pittsburgh, PA). Certified reference material (BD284 matrix: milk powder; European Reference Materials [ERM]) in powder form witho.44- 0.06 $\mathrm{mg} / \mathrm{kg}$ AFM1 was purchased from Sigma-Aldrich (St. Louis, MO).Working standard solutions ranging in concentration from 0.01 to $5.0 \mathrm{mg} / \mathrm{L}$ were prepared daily for HPLC.

\section{Sample preparation}

For infant powdered milk (IPM) samples, a volume of $20 \mathrm{~mL}$ of $0.01 \mathrm{~mol} / \mathrm{L} \mathrm{PBS} \mathrm{pH} 7.4$ was added to $4 \mathrm{~g}$ of IPM and $1.8 \mathrm{~g}$ of $\mathrm{NaCl}$ and shaken at $200 \mathrm{rpm}$ for $15 \mathrm{~min}$, and the volume was adjusted up to $25 \mathrm{~mL}$ with $0.01 \mathrm{~mol} / \mathrm{L} \mathrm{PBS} \mathrm{pH} \mathrm{7.4.}$ After the IPM samples were centrifuged at $1670 \times g$ for $20 \mathrm{~min}$, the fat layer was removed, and the supernatant was filtered using two glass fiber filters (GA-200 followed by GA-55, Advantec, and Tokyo, Japan); the supernatant defatted (skim) milk was collected and used for further analysis.

Milk powders were accurately weighed (10g), and added into a $250 \mathrm{~mL}$ beaker then $80 \mathrm{~g} \mathrm{H}_{2} \mathrm{O}\left(40^{\circ} \mathrm{C}\right)$ was added, shaking to mixture continuously until a homogeneous mixture is obtained. Transfer milk mixture to a $250 \mathrm{~mL}$ measuring cylinder, and bring the volume to $100 \mathrm{~mL}$ with the remaining preheated water. Centrifuge two $50 \mathrm{~mL}$ samples at 2,000 rpm for 15 minutes. After centrifugation fat layer was removed and the supernatant defatted (skim) milk was collected and used for further analysis.

Supernatant solution (20 $\mathrm{mL}$ ) was applied to an OASIS HLB cartridge which had previously been conditioned with $5 \mathrm{~mL}$ acetonitrile and $5 \mathrm{~mL}$ 
water, successively. The column was washed with $10 \mathrm{~mL} 20 \%$ acetonitrile aqueous solution. The AFM1 were eluted with $5 \mathrm{~mL}$ acetonitrile and the eluate was collected and evaporated to dryness using gentle stream of nitrogen. The residue was reconstituted with $1.0 \mathrm{~mL}$ of $20 \%$ aqueous acetonitrile and the obtained solution was forced through a PTFE syringe filter (pore size $0.45 \mathrm{~mm}$ ). The Association of Official Agricultural Chemists (AOAC) official method 2005 using HPLC coupled with fluorescence detector (AOAC 2005) was used to analyze AFM1 in milk powder infant powdered and milk samples (Van Egmond and Dragacci, 2001).

\section{HPLC Analysis}

HPLC (Alliance 2690 Separation Module System, Waters, Milford, MA) equipped with a fluorescence detector (Model 474, Waters) was used to separate and detect AFM1. A C18 reversephase column (Capsell PAK $4.6 \mathrm{~mm} ¥ 250 \mathrm{~nm}, 5$ $\mathrm{mm}$, Shisheido, Tokyo, Japan) was used to separate AFM1 and was maintained at $30^{\circ} \mathrm{C}$ in a column chamber. The mobile phase consisted of acetonitrile and water $(25: 75, \mathrm{v} / \mathrm{v})$, and was pumped at a flow rate of $0.8 \mathrm{~mL} / \mathrm{min}$. AFM1 was detected at an excitation and emission wavelength of 365 and $450 \mathrm{~nm}$, respectively. The $R 2$ value of the linear regression for the AFM1 calibration curve was >0.999. Twenty microliter of the raw milk sample reconstituted in the mobile phase was injected into the system.

\section{AFM1dietary intake estimations}

\section{Estimated Daily Intake (EDI) for AFM1 for Infants}

The EDI of AFM1 for infants was estimated from relationships between the daily milk intakes, i.e., the volume of milk consumed by infants, the mean AFM1 contamination in infant powdered milk samples.

$\mathrm{EDI}(\mathrm{ng} / \mathrm{kg}$ b.w./day $)=\frac{\text { Daily milk intake } \times \text { Mean AFM1 concentration }}{\text { Average body weight }}$

Volume of milk consumed by infants $=100+(10 \times$ age in months)
Frequency of nappies per day: From one day old to 6 months 6-7 nappies; from 7 months to 9 months 5 nappies and from 10 to 12 months 4 nappies / day. Healthy infants should generally have six or more very wet nappies a day (Ministry of Health, 2008). Guidelines for quantities and frequency of feeds are printed on the formula cans (NHMRC, 2006); the milk consumption considered was 590, 630,650 and $820 \mathrm{~mL}$ for ages one week, one month, six months and 12 months, respectively. For the volume of milk consumed by infants, it was considered that $4.52 \mathrm{~g}$ (a measurement) of Infant Powdered Milk was required to prepare $30 \mathrm{~mL}$ milk according to the manufacturers.

\section{Estimated Daily Intake (EDI) for AFM1 for adults}

The estimates of dietary exposure to AFM1 were calculated from the amount of the compound found in dairy products $(\mathrm{ng} / \mathrm{kg}$ ), the daily intake of dairy products by the adult (g), and the mean body weight of the adult human $(\mathrm{Kg})$.The overall daily milk consumption levels for adults considered 437 $\mathrm{mL} /$ day. The exposure was calculated deterministically by multiplying mean contamination level with mean consumption level and divided by body weight of estimated average $60 \mathrm{~kg}$ for adults based on mycotoxin safety evaluation for intake (FAO/WHO, 2001).

\section{Statistical analysis}

Data were analyzed by using SPSS, and the AFM1 levels were expressed in $(\mathrm{ng} / \mathrm{kg})$.

\section{Results and discussion}

A total of one hundred samples of (infant powdered milk formulas and powdered milk, 50 each) were collected at random from different groceries and supermarkets in El Behera, Egypt and analyzed for AFM1 contamination. Results presented in (Table 1) revealed that $6(12 \%)$ of infant powdered milk samples and $12(24 \%)$ of examined powdered milk were contaminated withAFM1 and 4(8\%) of infant powdered milk and $6(12 \%)$ of powdered milk samples having AFM1 level above the permissible limit ofAFM1 $(25 \mathrm{ng} / \mathrm{kg})$ and $(50 \mathrm{ng} / \mathrm{kg})$ set by European commission (EC, 2010) for infant powdered milk and powdered milk for adult consumption; 
respectively. Higher incidence in milk powder was reported by Zakaria et al. (2018).

In the present study the low incidence of AFM1 in branded Infant Powdered Milk may be attributed to strict inspections applied during the production system and control precautions of the animal feeding before milk production. Results also revealed that the mean AFM1 level in infant powdered milk samples was $(17.3 \pm 1.29 \mathrm{ng} / \mathrm{kg})$ and the mean AFM1 level found in milk powder samples was $(15 \cdot 9 \pm 2.26 \mathrm{ng} / \mathrm{kg})$. These values were lower than the values given by Omar (2016), Awaisheh et al. (2019) and Quevedo-Garza (2020) in infant formulae. Lower results were reported by Peng and Chen (2009), El-Tras et al. (2011) and Elsayed and Abd El-Fatah (2015) in infant powdered milk.AFM1 is considered as a threatening toxin and is dangerous to public health because of its carcinogenic and hepatotoxic, teratogenic and mutagenic effects in humans and animals (Herzallah, 2009).

Table 1. AFM1 levels in examined infant powdered milk formulas and powdered milk for adult consumption samples retailed in ElBehera, Egypt.

\begin{tabular}{llllll}
\hline \multirow{2}{*}{ Product } & $\begin{array}{l}\text { No of } \\
\text { examined } \\
\text { Samples }\end{array}$ & \multicolumn{2}{l}{ Positive samples } & $\begin{array}{l}\text { Range of } \\
\text { concentration } \\
\text { (ng/kg) }\end{array}$ & Mean (ng/kg) \\
\cline { 2 - 6 } & No & $\%$ & \% & Nd- 55 & $13.7 \pm 1.29$ \\
\hline Infant powdered milk & 50 & 6 & $12 \%$ & Nd-65 & $15.9 \pm 2.26$ \\
\hline Powdered milk & 50 & 12 & $24 \%$ & \\
\hline
\end{tabular}

$\mathrm{Nd}=$ Not Detected

Chemically AFM1 is a water-soluble component. AFM1 is resistant to thermal inactivation and is not destroyed completely by pasteurization, sterilization, and other varieties of food-processing procedures and storage of dairy products (Maktabi and Fazlara 2011). Because AFM1 is thermostable $\left(120^{\circ} \mathrm{C}\right)$ and is not readily destroyed or removed by chemical and physical treatments, monitoring AFB1 levels in animal feeds is essential to minimize AFM1contamination in infant powdered milk (JECFA, 2001).

Results presented in Table 2 showed that Estimated daily intake (EDI)was (81, 63.93, 37.57 and 39 ) $\mathrm{ng} / \mathrm{kg}$ body weights for (one week of age, one month, 6 months and 12 months of age for infants; respectively and EDI from powdered milk for adults was $14.24 \mathrm{ng} / \mathrm{kg}$ body weights(3able 3 ). Higher results in infant powdered milk were reported by Awaisheh et al. (2019). Lower average daily exposure was reported by El-Tras et al. (2011) in infant milk formulas. The calculated average of infant daily exposure to AFM1 from one week of age to and 12 months; indicated highly exposure values. The important issue emerges here is the high-risk possibility of infant's exposure toAFM1 from infant powdered milk in Egypt. There is a link between growth impairment in children and exposition to mycotoxins shown in several epidemiological studies (Khlangwiset et al.
2011). Exposure to AFM1 is most likely to occur through the frequent consumption of milk and milk by-products e.g. (infant milk) Caloni et al., (2006).The estimated daily intake of AFM1 in milk was investigated by the JECFA (2001); the intake of AFM1 was $0.002 \mathrm{ng} / \mathrm{kgbw} /$ day in the African diet and the average dietary intake of AFM1 for adults was $3.5 \mathrm{ng} /$ person/ day (JECFA, 2001). The daily intake of AFM1 in this study for adults was much higher than $(3.5 \mathrm{ng} / \mathrm{kg})$. Afltoxins are assigned as a hepatotoxic, mutagenic, teratogenic, immunosuppressive, and neoplastic (Lereau et al., 2012).

AFM1 has been demonstrated to be cytotoxic on human hepatocytes in vitro, and its acute toxicity in several species is similar to that of Aflatoxin B1; liver cancer has been related to dietary intake of Aflatoxins (Henry et al., 2001; Makun et al., 2012). The findings of the current study indicated high estimated daily intake of AFM1 content in examined infant powdered formulas and milk powder samples accordingly raised the need to reinforce application of good agricultural and good hygienic practices as preventive and control measures to decrease AFM1 in milk and infant powdered milk through controlling AFB1 in feed at the farm level. Moreover, it is very important to setup clear legal limits of AFM1 in infant powdered milk in Egyptian standards. 
Table 2. Estimated daily intake by infants through infant powdered milk.

\begin{tabular}{llll}
\hline Age & $\begin{array}{l}\text { Milk consumption } \\
(\mathbf{m L})\end{array}$ & $\begin{array}{l}\text { Average weight } \\
\text { (kg) }\end{array}$ & $\begin{array}{l}\text { Estimated daily intake (ng/kg } \\
\text { b.w./Day) }\end{array}$ \\
\hline 1 week & 590 & 3.3 & 81.0 \\
1 month & 630 & 4.5 & 63.93 \\
6 months & 650 & 7.9 & 37.57 \\
12 months & 820 & 9.6 & 39.0 \\
\hline
\end{tabular}

Table 3. Estimated daily intake of AFM1 by adults through powdered milk.

\begin{tabular}{llll}
\hline Age & $\begin{array}{l}\text { Milk Consumption } \\
(\mathbf{m L})\end{array}$ & $\begin{array}{l}\text { Average Weight } \\
(\mathbf{k g})\end{array}$ & $\begin{array}{l}\text { Estimated Daily Intake } \\
(\mathbf{n g} / \mathbf{k g ~ b . w . / D a y})\end{array}$ \\
\hline Adults & 437 & 60 & 14.24 \\
\hline
\end{tabular}

\section{Conclusion}

Results of this study indicated that AFM1 could be available in milk powder and infant powdered milk made from contaminated milk. Consequently, this subject is a serious problem for the public health since all the age groups including infants and children consume these products worldwide. Therefore, continuous monitoring of AFM1 and establishing a maximumAFM1 limit in the food legislation for infant powdered milk formulas and powdered milk are required due to the higher susceptibility of infants to mycotoxin contamination compared to adults.

\section{Conflict of interest statement}

Author declares that there is no conflict of interest.

\section{References}

AOAC, 2005. Association of Official Agricultural Chemists Official Method 2000.08 Aflatoxin M1 Liquid Milk, Immunoaffinity Column by Liquid Chromatography, 49.3.07, 18th Ed., AOAC, Gaithersburg, MD.

Ameur, S. M., Dahmane, M., Brera, C., Kardjadj, M., Ben-Mahdi, M. H., 2020. Occurrence and seasonal variation of aflatoxin M1 in raw cow milk collected from different regions of Algeria. Vet. World. 13(3), 433-439.

Awaisheh, S. S., Rahahleh, R. J., Algroom, R. M., Al-Bakheit, A. A., Al-Khaza'leh, J. M., AlDababseh, B. A., 2019. Contamination level and exposure assessment to aflatoxin M1 in Jordanian infant milk formulas. Italian J. Food Saf. 8, 127-130.

Boudra, H., Barnouin, J., Dragacci, S., Morgavi, P.,
2007. Aflatoxin M1 and ochratoxin A in raw bulk milk from French dairy herds. J. Dairy Sci. 90, 3197-3201.

Caloni, F., Stammati, A., Friggè, G., De Angelis, I., 2006. Aflatoxin M1 absorption and cytotoxicity on human intestinal in vitro model. Toxicon. 47, 409-415.

Creppy, E. E., 2002. Update of survey, regulation and toxic effects of mycotoxins in Europe. Toxicol. Lett. 127, 19-28.

Elsayed, M. S., Abd El-Fatah, E. N., 2015. Prevalence of aflatoxin M1 in some milk products widely consumed by infants and children, marketed in Sharkia. Egypt. J. Global Vet. 14(4), 560-566.

El-Tras, W. F., El-Kadyand, N. N., Tayel, A. A., 2011. Infants exposure to aflatoxin $\mathrm{M} 1$ as a novel foodborne zoonosis. J. Food Chem. Toxicol. 49: 2816-2819.

European Commission (EC), 2010. Commission Regulation (EC) No. 165/2010 of 26 February of 2010 Amending Regulation (EC) No. 1881/2006 Setting Maximum Levels for Certain Contaminants in Foodstuffs as Regards Aflatoxins. EUR-Lex. Available online: http://eurlex.europa.eu/legalcontent/EN/TXT /PDF/?uri=CELEX: 32010R0165\&from =EN

Food and Agriculture Organization (FAO) / World Health Organization (WHO), 2001. Expert Committee on Food Additives (JECFA). International Programme on Chemical Safety: Safety Evaluation of Certain Food Additives; WHO: Geneva, Switzerland.

EFSA, 2004. Opinion of the scientific panel on contaminants in the food chain on a request from the commission related to aflatoxin $\mathrm{B} 1$ as undesirable substance in animal feed. Eur. Food Stand. Agency J. 39, 1-27. 
Fallah, A. A., Jafari, T., Fallah, A., Rahnama, M. 2009. Determination of aflatoxinM1 levels in Iranian white and cream cheese. Food Chem. Toxicol. 47, 1872-1875.

Henry, S. H., Whitaker, T., Rabbani, I., Bowers, J., Park, D., Price, W., Bosch, F. X., 2001. Aflatoxin M1. (JECFA) 47. Joint FAO/ WHO Expert Committee on Food Additives (JECFA).

Herzallah, S.M., 2009. Determination of aflatoxins in eggs, milk, meat and meat products using HPLC fluorescent and UV detectors. Food Chem. 114, 1141-1146.

International Agency for Research on Cancer, 2002. Some Traditional Herbal Medicines, Some Mycotoxins ,Naphthalene and Styrene, IARC Monographs on the Evaluation of Carcinogenic Risks to Humans; IARC Press: Lyon, France. Vol. 82.

FAO \& WHO Expert Committee on Food Additives (JECFA), 2001. Safety Evaluation of Certain Mycotoxinsin Food. Prepared by the 56th Meeting of Food Additives Series. Vol. 47, Available online: http://www.inchem.org/ documents/jecfa/jecmono/v47jeo2.htm

Khlangwiset, P., Shephard, G. S., Wu, F., 2011. Aflatoxins and growth impairment: a review. Crit. Rev. Toxicol. 41(9), 740-755.

Lereau, M., Gouas, D., Villar, S., Besaratinia, A., Hautefeuille, A., Berthillon, P., MartelPlanche, G., Nogueira da Costa, A., Ortiz Cuaran, S., Hantz, O., et al., 2012. Interactions between hepatitis B virus and aflatoxin B1: effects on p53 induction in Hepa RG cells. J. Gen. Virol. 93, 640-650.

Maktabi, S., Fazlara, A., 2011. Contamination of ice cream by aflatoxin M1 in Iran. Amer.-Eur. J. Toxicol. Sci. 3(3), 120-123.

Makun, H. A., Dutton, M. F., Njobeh, P. B., Gbodi, T. A., Ogbadu, G. H., 2012. Aflatoxin contamination in foods and feeds: A special focus on Africa. In: Trends in Vital Food and Control Engineering. Intech, Rijeka, Croatia, pp. 188-234.
Ministry of Health, 2008. Food and Nutrition Guidelines for Healthy Infants and Toddlers (Aged 0-2): A background paper (4th Ed) Partially Revised December 2012. Wellington: Ministry of Health.

NHMRC (National Health and Medical Research Council), 2006. Nutrient Reference Values for Australia and New Zealand Including Recommended Dietary Intakes .Canberra and Wellington: National Health and Medical Research Council and Ministry of Health.

Omar, S.S., 2016. Aflatoxin M1 levels in raw milk, pasteurized milk and infant formula. Italian J. Food Saf. 5, 158-160.

Peng, K. Y., Chen, C. Y., 2009. Prevalence of aflatoxin $\mathrm{M} 1$ in milk and its potential liver cancer risk in Taiwan. J. Food Prot. 72(5), 1025-1029.

Prandini, A., Tansini, G., Sigolo, S., Filippi, L., Laporta, M., Piva, G., 2009. On occurrence of aflatoxin M1 in milk and dairy products. Food Chem. Toxicol. 47, 984-991.

Quevedo-Garza, P. A., Amador-Espejo, G. G., García, R. S., Ramos-Peña , E. G., Trujillo, A.J., 2020. Aflatoxin M1 determination in infant formulae distributed in Monterrey, Mexico. J. Toxins. 12, 100.

Shundo, L., Navas, S.A., Lamardo, L. C. A., Ruvieri, V., Sabino, M., 2009. Estimate of aflatoxin M1 exposure in milk and occurrence in Brazil. Food Control. 20, 655-657.

Van Egmond, H.P., Dragacci, S., 2001. Liquid Chromatpgraphic Method for Aflatoxin M1 in milk. In: Methods in Molecular Biology, Vol. Mycotoxins (Eds.: Epohland, A., Trucksess, M.W.). Humana Press, Totowa, NJ, USA. 157, 59-69.

Zakaria, A.M., Ombarak, R.A., El Kamshishy, M.M., 2018. Incidence of some food borne pathogens, heavy metal residues and aflatoxin M1 in imported skimmed milk powder. J. Food Nutr. 1(1), 1-4.

\section{How to cite this article:}

El-Ansary, M. A., 2020. Infant powdered milk formula and milk powder as a potential risk for developing children in terms of Aflatoxin M1. Int. J. Curr. Res. Biosci. Plant Biol. 7(7), 41-46.

doi: https://doi.org/10.20546/ijcrbp.2020.707.004 